\title{
On the Use and Abuse of Biography: Lenger's Sombart
}

\author{
ARTHUR MITZMAN
}

LeNGer, FrIedrich. Werner Sombart 1863-1941: eine Biographie. C.H. Beck, München 1994. 570 pp. DM 98.00.

The abundant oeuvre of the German economist and sociologist Werner Sombart (1863-1941) has long merited an attention it has not received. Sombart served as a weathervane for his generation and social class. Optimistic and progressive in the 1890 s, he succumbed to the prevalent Kulturpessimismues of the decade before World War I; during the Weimar period; he ventured more and more towards a reactionary populist nationalism, maintaining only a thin, if important, distance from Nazism - in fact, it was the thinness of this distance which has been the major source of his neglect. Meanwhile, as the colleague of Ferdinand Tönnies and Max Weber, he helped found the discipline of sociology, integrating Tönnies' distinction of Gemeinschaft/Gesellschaft into his histories of economic life as well as into his cultural criticism, and debating with Weber on value freedom and the religious sources of the spirit of capitalism.

Friedrich Lenger has written an impressive, thorough study of Sombart. He has scrutinized every aspect of the evolution of his ideas to show their major and minor turning-points. He has examined carefully the reception of Sombart's ideas and turned over every scrap of evidence about the networks of friends and colleagues in which he lived and advanced his career, so as to illuminate the social and intellectual frameworks of those ideas and that career. He has also studied carefully Sombart's social background, life-style and income, to place him in the stratum of the wealthy, educated and influential Bildungsbiurgertum. All in all, his book is a major contribution to the sociology of knowledge.

Lenger's approach, as he is aware, signals a turning-point in the significance attributed to individuals in the German historical discipline, which for several decades has been dominated by the structuralist hostility to biographical studies epitomized in the views of Hans-Ulrich Wehler. A sociological quest for the grand structures that led German society to enthusiastic support for Nazism, together with a methodological aversion to the earlier focus in German history on individual genius or malevolence - in casu, Hitler's "demonic" charisma - as the catalyst of historical development, has for some time focused the attention of serious German historians on the collective social, economic and political problems unleashed by Germany's Bismarckian unification and made it 
difficult for them to see any value in the study of individuals and their work. Among French historians, a similar paradigm, without the specific focus on the sources of twentieth-century barbarism, long hampered serious attention to biographical studies. The school of the Annales has only slowly emerged from the Braudelian obsession with long- and middle-term structures and conjunctures to examine the subjective, experiential sides of human behavior: first through the examination of collective "mentalities", then increasingly through the lens of "representations" and individual experience. ${ }^{1}$

In the case of Lenger, this interest in the individual side of human experience becomes principally a contextualized history of Sombart's ideas. The ideas are clearly presented, from Sombart's earliest studies of the dependent relations of Italian peasants, through his revisionist socialist phase in the 1890s (Sozialismus und Soziale Bewegung, 1895, his first bestseller, which had numerous new editions until he refuted most of it in his ferociously anti-Marxist Der proletarische Sozialismus, 2 vols, 1924), to his various efforts to conceptualize his increasing social conservatism (Die deutsche Volkswirtschaft im 19e Jahrlundert, 1903; the articles in Morgen [1906/1908]; Der Bourgeois, 1913; Deutscher Sozialismus, 1934), to his three-decade-long study of the genesis and evolution of modern capitalism and the capitalist spirit (Der moderne Kapitalismus, 2 vols, 1902; the second edition of Der moderne Kapitalismus, 6 vols, 1916-1927 as well as his numerous studies on the relation to capitalism of luxury, warfare, the Jews, etc.), to his efforts to give the new discipline of sociology a theoretical basis in various articles in the Archiv für Sozialwissenschaft und Sozialpolitik (which he edited jointly with Max Weber) and in Noo-Soziologie (posthumous publication, Berlin 1956).

Through all of this scrupulously detailed history of Sombart's ideas, Lenger retains a powerful focus on their social-historical and political frameworks, three of which dominate his study. First, like many other historians, he views the Bildungsbürgertum as a sort of hegemonic stratum in German society since the Bismarckian unification. He prefers this sociological construction, which designates a group of educated bourgeois whose economic and political interests are masked, but not replaced, by a powerful national-cultural tradition, to the rather worn-out Mannheimian notion of the freischwebende Intelligenz and he carries out a "microscopic" (p. 13) analysis of Sombart's values, life-style and income as an important example of it. Within this overarching frame of the Bildungsbiirgertum, Lenger privileges Sombart's relation to the

The shift was acknowledged in the editorial statement of 1988, "Histoire et sciences sociales: un toumant critique", Annoles Economies Sociefés Civilisations (1988), pp. 291293. It has since been consecrated in the renaming of the review to Annales Histoire, sciences sociales. 
professional and organizational structures of the Verein fïr Sozialpolitik, the Gesellschaft für Soziologie and the German university world. With regard to the last, Lenger shows how the opposition of Gustave Schmoller and the Prussian Education Minister Althoff to Sombart's early pro-Marxism kept him out of a professorship at a first-rate university until World War I, when his violently Anglophobic Händler und Helden brought him into official favor.

Lenger's second emphasis is on Sombart's relation to socialism, to the trade union movement and to groups like the Gesellschaft für ethische $K u l t u r$, which tried to mediate between radical working-class movements and the Bildungsbiurgertum. He illustrates this relationship by numerous examples of the personal closeness of the young Sombart to Heinrich Braun and the Swiss social democrat Otto Lang and to the political ambiance of Breslau, where Sombart taught economics at the university for the first part of his career and where he animated one of the few effective coalitions in Germany between left-leaning leaders of the Bildungsbiirgertum (many of them Jewish) and right-wing (revisionist) socialists.

'Lenger's third emphasis is on the way German public and political opinion received Sombart's ideas, from the beginning to the end of his long and prolific career. This frame becomes extremely important in the latter part of the book, where Sombart's ideas do a curious dance around those of the "Conservative Revolution", fascism and Nazism. Thanks to Lenger's documentation, we see that notwithstanding the vehemence of his anti-semitism and whatever his sympathies may have been for fascism and for the Strasser brand of Nazi ideology, Sombart's celebration of Geist over racist "biologism", the hoary conservatism of his reverence for peasant societies and his near-ecological skepticism for modern technology brought him into disfavor and led to his ostracism (if not persecution) by the Nazis. Indeed his antipathy to racism and to the Hitlerian Führercult (Sombart once referred to the adherents of that cult as the "Hakenkreuzler"), his general unwillingness to adapt his ideas or the organizations he was responsible for to the totalitarian state, and his friendship for some of those subsequently involved in the officers' resistance of 1944 , led Lenger to conclude that had he lived long enough, Sombart too might have participated in that resistance. Such a denouement would, he argues at the end of his book, have given the post-war evaluation of Sombart a totally different coloration than the ugly impressions of anti-semitism and extreme nationalism that have prevailed, and would have led to a more fruitful use of his often brilliant insights and theories (p. 387).

No doubt. Yet this fascinating "contra-factual" conclusion, coming as it does in the place of any evaluation of the significance of Sombart's life and works, gives Lenger's "biography" more the character of an "anti-biography". What makes his approach particularly interesting is 
his theoretical justification for it. Taking a leaf from the postmodem deconstruction of the "subject" and referring the reader to Pierre Bourdieu's notion of the "biographical illusion" Lenger writes:

If I have sketched, playfully, some hypothetical biographies of Werner Sombart, to which others could easily be added, such as that of the cultural critic who died in 1908 or of the early ecologist or meritorious social liberal of the 1890s, it is not merely a question of the later reception or of the unrealized alternatives oi a life story. The problem is rather that the perspectives on someone's life are determined by its completely contingent conclusion. One avoids this arbitrariness not by the positing of an alternative telos, either of the history of the subject's work or of his political emplacement, but only through a radically genetic and contextualizing approach which respects the autonomous logic of his different fields of action. The resultant partial fragmentation of the life history presented here is nonetheless intentional insofar as it appears to be the only way of avoiding the "biographical illusion", "that 'a life' constitutes a totality, a coherent and oriented continuity which can and must be conceived as the unified expression of a subjective and objective 'intention', of a Project".'

Yet one wonders if this highly sophisticated démarche necessarily has to be accompanied by the rather sketchy presentation of the personal side of Sombart's life and by the systematic inattention to the relation between personal experience and work, that we find in Mr Lenger's book. Many questions of importance, for which Lenger himself provides documentary evidence, are simply evaded in this book: the influence on his early work, for example, of the estrangement between the young Sombart and his father, a founding member of the Verein fur Sozialpoli$t i k$, who strongly disapproved of Werner's pro-socialist positions in the 1890 s, and the significance of his gradual rapprochement with the father's social outlook in the years after the old man's death; the significance, in the context of Wilhelmian society, of his "homo-social" relations with fellow rebels and intellectuals such as Otto Lang, Heinrich Braun and Carl Hauptmann; the sources and significance of Sombart's separation from wife and family and of his notorious Don-Juanism during the

2 Wenn hier spielerisch einige hypothetische Biographien Werner Sombarts skizziert worden sind, denen muhelos weitere, wie die des 1908 verstorbenen Kulturkritikers und fruhen Ökologen oder des verdienten Sozialliberalen der 1890er Jahre, hinzugefugt werden könnten, dann geht es nicht allein um die spätere Rezeption oder um die nicht realisierten Alternativen eines Lebenslaufs, sondern um die von einem gănzlich kontingenten SchluBpunkt bestimmten Perspektiven auf ein Leben. Dieser Beliebigkeit entgeht man nicht durch die Setzung eines alternativen Telos, sei es werk- oder politikgeschichtlicher Natur, sondern nur durch einen radikal genetischen und kontextualisierenden Zugriff, der die Eigenlogik verschiedener Handlungsfelder respektiert. Die daraus resultierende partielle Zerrissenheit der hier vorgelegten Lebensgeschichte is insofern beabsichtigt, erscheint sie doch als der einzige Weg, um der "biographischen Illusion" zu entkommen, "daß "das Leben' ein Ganzes konstituiert, einen kohärenten und orientierten Zusammenhang, der als ein einheitlichter Ausdruck einer subjektiven und objektiven 'Intention', eines Projekts aufgefaßt werden kann und muB." 
decade and a half before World War I (it almost seems as if his personal behavior became more libertine as his social philosophy became more conservative); the character of his second marriage and its impact on his ideas during the Weimar Republic. Which is not to ask Mr Lenger to succumb to the reductionist fallacy of attributing all significance in someone's career and historical impact to his or her personal life history. But surely there is a correlation worth examining between the changing contours of Sombart's ideas, his emotional life-course and the tense relation sustained by his generation of young rebels with the Bildungsbiurgertum that most of them ultimately merged with. In fact, the refusal to attribute to that intimate aspect any significance whatever for the career and impact of an author is as one-sided as the ignorance of his social and intellectual contexts.

I have nothing but admiration for the information about Sombart's context that Friedrich Lenger has produced. His 1,500 notes are impeccable, his four-part, 55-page bibliography comprehensive. He has gone to every conceivable manuscript source, from the Geheimes Staatsarchiv Merseburg (which was closed to me when I worked on Sombart thirty years ago) to the private archives of Nikolaus Sombart (in all 28 archives are listed in his index of archival holdings). As a result, we not only have a very broad picture of Sombart's friendships and networks among fellow sociologists, with colleagues, writers and artists in Breslau, Berlin and Schreiberhau - but we are truly able to place him in the intellectual and political currents of his long and active life. Yet what we end up with is the frame for a life without the life. There are reasons for this that have little to do with avoiding the "biographical illusion".

For one thing, the notion that a biography is in the first place an invention of the biographer (inherent in the concept of the "biographical illusion") and therefore not "scientific" is one which can easily be expanded to every work of scholarship, including Lenger's. He has defined a number of areas in which he thought it worth while to place Sombart, not because these are given him by some logos of objective truth but because the present scholarly and political conjuncture in Germany make it meaningful to examine these areas: the life-style, living standard, social role and significance of the Bildungsbiurgertum in the period 1890 to 1930; the intellectual currents around revisionist Marxism in the period before World War I and around the "Conservative Revolution" in the decade before Hitler's accession to power; the specific relation of his subject to National Socialism. While Lenger's evidence and conclusions regarding these questions may be assessed by some conventionally agreed on historical method, both that method and the questions he has posed are as much a construct of historians as any unified life-course ever was. One may argue that these constructs are all we have, which is true, but among them there is another construct which Lenger keeps at a distance: the notion that the intimate resonances 
of an individual life, in its coherences and incoherences, may reflect a relation to society which is illuminating for social and cultural historians.

It goes without saying that every life reconstructed by a biographer is as much his invention as is any other work of history. But if it lacks the certainty of a statistical table taken from a census, if it is - perhaps! less certain than some kinds of sociological history, it is not a novel. Its findings are subject to the same kind of professional interrogation as a monograph about the education and income of the Bildungsbürgertum. It is in any case more reasonable and less abstract to assume the existence of an individual life than of a social group.

Moreover, while the biographical arts of the nineteenth century may have assumed both the seamless totality and the leading historical role of the Great Men who were the objects of those arts, the fact that we no longer accept either such totality or the dominance of history by leading personalities is no reason to deny a priori the significance of individual lives as barometers of their times, in particular as barometers for the collective emotional storms that, as we have learned to our misfortune, have swept over the historical landscape like tornados, turning the carefully built historical structures cherished by institutional historians into driftwood. The question is not whether we can view a life as a coherent unity with some kind of final goal but whether the intimate experiences of that life (a) can be structured in some kind of meaningful way and (b) are historically relevant.

Friedrich Lenger is aware of some of these problems. His introduction has an interesting page on his reasons for resisting the psychohistorical temptation. He argues that the available source materials "generally [are] not really sufficient (tragfähig) for a post-hoc psychoanalysis" and that "all to often, speculations then come in the place of an interpretation oriented by theory". Citing a phrase from my own meager effort ten years ago to compare Weber's and Sombart's personalities, ${ }^{3}$ he condemns that attempt, saying, "Werner Sombart too has not been spared by 'the lack of ego-documents and an adequate biography' from becoming the object of such a free-floating [psychoanalytic] interpetation" (p. 15). What Lenger does not mention is that the quoted phrase (which of course precludes speculation) referred specifically to Sombart's relation to his mother, and that, in consequence, my brief sketch left untouched that part of the comparison with Weber (about whose relation to his mother there is extensive documentation) and focused on other, documented, aspects of his emotional life, one part of which, his vexed

'A. Mitzman, "Personal Conflict and Ideological Options in Sombart and Weber", in W.J. Mommsen and J. Osterhammel (eds), Max Weber and his Contemporaries (London, 1987). I should mention that Lenger generously praises my earlier, more extended treatment of Sombart in Sociology and Estrangement (1973) as a "für die Zeit vor dem Ersten Weltkrieg eingehende Interpretation der wichtigsten Veröffentlichungen Sombarts" and describes it as a "considerable progress" over earlier studies (p. 20). 
relationship to his father, is indeed comprehensible in terms of Freudian theory, while another, his extremely important peer-friendships, is not.

In both cases, however, I attempted something which Lenger, with his wealth of information, could have done much more effectively. I tried to show how Sombart's personality and the ideological options he chose at different points in his career were both rooted in larger socialcultural problems: one was the generational conflict between 1890 and World War I, which underlay not merely the resistance of younger social scientists such as Sombart and Weber to the older generation of Kathedersozialisten (Schmoller, Wagner, Sombart Senior, etc.) but such disparate manifestations of anti-establishment peer-group sentiment as the George-Kreis, the Nietzsche-cult, expressionism in the arts and the youth movement as well. Another, related to the first but having its own source in the inability of German liberalism to unite to it at least an important part of the pre-industrial masses most injured by the rise of Modernity, was the rise in the same fin de siecle of reactionary Mittelstand movements of discontent, in which anti-semitism, celebration of the peasant and artisan and Völkisch nationalism went hand in hand. While Sombart may always have been an interesting, if deviant, example of the Bildungsbilirgertum, his evolution as such from the first of these frameworks to the second, an evolution which began well before World War I and reached its apotheosis in his Deutscher Sozialismus of 1934, may reveal more about the inability of the bourgeoisie as a whole to resist Nazism than the highly interesting details concerning Sombart's half-hearted opposition to the Gleichschaltung of German scholars into the Third Reich.

The problem that plagues Lenger's biography is not that these frameworks are unknown to him (as a sophisticated historian of his country's society and culture, he knows more about them than I do), but that he remains hampered by historiographical convention from integrating into his understanding of them a serious consideration of the personality and character of his subject. For what can bring both of these rather abstract frameworks to life, and what can clarify our understanding of how they relate to individual existences, is precisely a biographical approach that takes the emotional experience of its subject seriously. A dogmatic Freudianism is of course useless in such an undertaking. But a history "informed by psychoanalysis" that links intimate experience to social matrix is no more reducible to such dogmatism than a sophisticated analysis of class interest and culture can be identified with vulgar Marxism. ${ }^{4}$

4 Fruitful examples of such a linking of intimate experience and personal evolution to social frameworks and ideologies can be found at both the individual and the collective level: Jan Fontijn's prize-winning biography of Frederik van Eeden, Tweespalt (1990) exemplifies the first category, while George Mosse's Nationalism and Sexuality (1985), John Demos, Entertaining Satan, Witchcraft and the culture of Early New England (1982); 
Finally, it is a red herring to argue that psychoanalysis cannot be used in Sombart's case because there is insufficient information about his childhood. This would no doubt be true of an actual psychotherapy, but a simple effort to comprehend the adult conflicts and character of a well-known writer for whom we have extensive correspondence and the testimony of those who knew him is by no means dependent on such information, but can be deduced from the innumerable projections in personal relations and from the recurrent motifs in his writing. ${ }^{5}$ While any such approach may prove historically irrelevant if it fails to take account of the major shifts in a writer's values and their connection to the evolving ideologies and mentalities of his or her time, there is no reason to assume a priori the bankruptcy of efforts which do relate a personality to its time in this way.

Meanwhile, we should be thankful to Friedrich Lenger that he has brought to light so much fascinating material on Werner Sombart. If he has not written a biography, he certainly has unearthed - and presented the sources for one. He has fulfilled, brilliantly, the task he set himself of "contextualizing" Sombart's scholarly evolution. One can only hope that he can overcome his professional discomfort at confronting the intimate core of his subject to provide us with an historical interpretation of the personal side of that evolution as well.

Denis Bertholet's Le bourgeois dans tous ses états, Le roman familial de la Belle Epoque (1987) and Peter Gay, The Bourgeois Experience. Victoria to Freud (3 vols, 1984-1993), the second.

${ }^{5}$ The French literary critic Charles Mauron would go further than $I$ and argue that one can discern the "personal myth" of a writer in the recurrent metaphors in his or her oeuvre (Des Métaphores obsédantes au Mythe personnel. Introduction d la psychocritique, Paris, 1963). 